\title{
Infestation of the banana root borer among different banana plant genotypes
}

\section{Fernando Teixeira de Oliveira ${ }^{1}$ Pedro Manuel Oliveira Janeiro Neves ${ }^{1}$ Orcial Ceolin Bortolotto ${ }^{2}$}

${ }^{1}$ Universidade Estadual de Londrina (UEL), Londrina, PR, Brasil.

${ }^{2}$ Departamento de Agronomia, Universidade Estadual do Centro Oeste (UNICENTRO), Campus CEDETEG, Rua Simeão Camargo Varela de Sá, 03, Vila Carli, 85040-080, Guarapuava, PR, Brasil. E-mail: bortolotto.orcial@gmail.com. Corresponding author.

ABSTRACT: In this study, we aimed to investigate Cosmopolites sordidus (Coleoptera: Dryophthoridae) infestation among different banana genotypes in a commercial banana orchard over the course of 30 months. Banana root borer infestation was compared in 20 banana genotypes, including five varieties and 15 hybrids. Overall, we observed that $94.17 \%$ of pest infestation cases occurred in the cortex region, and only 5.83\% occurred in the central cylinder. Genotypes least sensitive to infestation were the Prata Anã (AAB) and Pacovan $(A A B)$ varieties, where no damage was recorded. Among the hybrid genotypes, PV 9401 and BRS Fhia 18 showed intermediate levels of sensitivity, while BRS Tropical hybrids (AAAB), PA 9401 (AAAB), BRS Vitoria (AAAB), YB 4203 (AAAB), and Bucaneiro (AAAA) were the most sensitive to attack by banana root borer. This study demonstrated that the infestation of the banana root borer varies according banana plant genotype, and the utilization of less susceptible genotypes could reduce infestation rates of $\boldsymbol{C}$. sordidus.

Key words: Musa spp., banana pests, varietal resistance, banana hybrids.

Infestação da broca-do-rizoma da bananeira em diferentes genótipos de bananeira

RESUMO: Neste estudo, objetivamos investigar a infestação de Cosmopolites sordidus (Coleoptera: Dryophthoridae) em diferentes genótipos de bananeira, em um pomar comercial de bananeira, com idade de 30 meses. Para isso, comparou-se a infestação da broca-da-rizoma em 20 genótipos de bananeira, sendo cinco variedades e quinze híbridos. No geral, foi observado que 94,17\% da infestação da praga ocorreu na região do córtex do rizoma, e apenas 5,83\% das plantas apresentaram infestação no cilindro central. Os materiais menos sensíveis à infestação foram as variedades Prata Anã (AAB) e Pacovan (AAB), nas quais não foi registrada ocorrência da praga. Entre os genótipos hibridos, de forma geral, os materiais PV 9401 e BRS FHIA 18 foram os que apresentaram sensibilidade intermediária, enquanto os hibridos BRS Tropical (AAAB), PA 9401 (AAAB), BRS Vitoria (AAAB), YB-4203 (AAAB) e Bucaneiro (AAAA) foram os mais sensiveis ao ataque da broca-do-rizoma. Este estudo demonstra que a infestação da broca-do-rizoma varia de acordo com o genótipo, e a seleção de materiais menos suscetiveis auxilia na redução da infestação de $\boldsymbol{C}$. sordidus.

Palavras-chave: Musa spp., pragas da bananeira, resistência varietal, hibridos de banana.

\section{INTRODUCTION}

The banana root borer, Cosmopolites sordidus (Coleoptera: Dryophthoridae), is a major banana plant (Musa spp.) pest worldwide (GOLD et al., 2001). The damage it causes is distinctive, and it can be detected directly by observation of the galleries in the rhizome of the plant (which debilitates banana plants) (ARLEU; SILVEIRANETO, 1984; DASSOU et al., 2015), or indirectly, since its presence leads to fungal infections that can compromise plant development (for example, Panama disease) (PEREIRA et al., 2005). In severe cases, the pest can cause losses of up to $100 \%$ of a banana orchard (SENGOOBA, 1986).
Currently, research has been directed toward the reduction or complete elimination of pesticide use in food production, encouraging the development of alternative strategies for pest control. In banana orchards, studies of the management of $\boldsymbol{C}$. sordidus have shifted to implementing microbial (AKELLO et al., 2008; LEMALÓPEZ et al., 2010; PAULI et al., 2011; FANCELLI et al., 2013; LOPES et al., 2013) and behavioral control (REDDY et al., 2009; ALPIZAR et al., 2012), as well as, more recently, environmental management (DASSOU et al., 2015). To expand the options for adequate pest management, researchers showed that planting bananas with genotypes that confer different levels of pestresistance to the plant is a possible strategy for management of the banana weevil. However, these studies have thus far been 
restricted to Africa (ORTIZ et al., 1995; KIGGUNDU et al., 2003a, b; KIGGUNDU et al., 2007; NIGHT et al., 2010; SADIK et al., 2010).

In Brazil, biotechnology has led to the development of hybrid banana genotypes with the potential for higher yields and resistance to fungal diseases (LIMA et al., 2005; DONATO et al., 2009). The response of these genotypes to infestation by the banana root borer; however, is still unknown, and this may negatively impact their usefulness. Therefore, in this study, we evaluated the susceptibility of banana plants with different genotypes to $\boldsymbol{C}$. sordidus infestation, grown in a commercial banana orchard.

\section{MATERIALS AND METHODS}

\section{Study site}

The study was carried out in the municipality of Andirá $\left(22^{\circ} 58^{\prime} 40^{\prime \prime} \mathrm{S}, 50^{\circ} 18^{\prime} 52^{\prime \prime} \mathrm{W}\right.$, altitude $\left.380 \mathrm{~m}\right)$, Parana State, Brazil, in October and November 2010. The study was conducted in a 30-month-old experimental banana orchard, characterized by a naturally occurring history of $\boldsymbol{C}$. sordidus infestation. To establish the orchard, banana plantlets were obtained from the Embrapa Mandioca e Fruricultura Tropical, and planted at a spacing of $3 \times 3$ meters. The soil classification of the experimental area was characterized as Oxisol, with medium clay texture (SANTOS et al., 2013).

\section{Experimental design and genotypes}

The study was conducted using a completely randomized experimental design. In total, 20 banana genotypes were compared using six replicates each, with each plot containing 20 plants. Each replicate was represented by one banana plant (also referred to as one experimental unit). The genotypes used in the study included five varieties: Grande Naine (AAA), BRS-Thap Maeo (AAB), Caipira (AAA), Prata Anã (AAB), Pacovan (AAB), and the 15 hybrids PV 9401 (AAAB), BRS Japira (AAAB), BRS Fhia Maravilha (AAAB), BRS Garantida (AAAB), BRS Vitoria (AAAB), BRS FHIA 18 (AAAB), BRS Pacovan Ken (AAAB), PA-9401 (AAAB), BRS Platina-PA 4244 (AAAB), YB 4203 (AAAB), BRS Princesa-YB 4207 (AAAB), BRS Tropical (AAAB), Bucaneiro (AAAA), FHIA 17 (AAAA), and FHIA 02 (AAAB).

\section{Monitoring the occurrence of $\boldsymbol{C}$. sordidus adults}

For 8 weeks prior to the experiment, the infestation of $\boldsymbol{C}$. sordidus adults was assessed weekly in the banana orchard. To monitor the presence of this pest, 12 bait-traps (fresh pseudostems) were distributed equidistantly in the area, using the cultivar Nanicão (since it is highly effective in attracting the pest). This methodology was repeated every 7 days, using fresh pseudostems each time. To avoid changing the dynamics of the pest population in the study area, all individuals captured were immediately released at the same site where they were collected.

During the 25 days before the experiment, the highest numbers of banana weevil adults were observed from September 21 to October 4, with an average of 7.1 insects captured per trap, indicating an infestation level above the action threshold (5 insects/trap) (PRANDO \& FERREIRA, 2004). This assessment revealed that adults of $\boldsymbol{C}$. sordidus were distributed equaly across the banana orchard and there was no single location with a higher abundance of pests; thereby, validating the results obtained in our experiments.

\section{Evaluation of borer rhizome infestation among the banana genotypes}

Assessment of the presence of the pest and of borer attacks on the plant rhizome was performed from October 20 to November 5, 2010, when the fruits were nearly ready for harvest. To study the infestation, rhizomes were randomly sampled from six plants of each genotype. For each plant, a cross-section of the rhizome was made at its maximum diameter, after which we observed the galleries formed by the banana root borers (MESQUITA, 1985).

To assess the attacked area, we developed a grid $(45 \times 45 \mathrm{~cm})$, composed of nylon wires $(0.60 \mathrm{~mm})$ forming cells of $1.5 \times 1.5 \mathrm{~cm}$. This grid was placed over the sliced rhizomes and the injured cells were quantified (symptoms of necrotic or dark tissue), and the diameter of the rhizome and the cortex of each plant was measured (in $\mathrm{cm}$ ). From these observations, it was possible to quantify infestation of both rhizome and cortex (\%), as well as the number of plants infested in the central cylinder and the level of central cylinder infestation (\%) in each banana genotype.

Our observations of the rhizome infestation allowed us to determine the coefficient of infestation (CI), following the methodology developed by MESQUITA (1985), according to the following damage scale (score): 0 (no galleries present), 5 (traces of galleries observed), 10 (between 5 and 20 galleries present), 20 (galleries in approximately $25 \%$ of the rhizome), 30 (galleries in approximately $20 \%-40 \%$ of the rhizome), 40 (galleries in approximately $50 \%$ of the rhizome), 50 (galleries in approximately $75 \%$ of the rhizome), and 100 (galleries in the entire rhizome).

\section{Statistical analysis}

The data were assessed by normality and homogeneity tests to verify that they met the assumptions of parametric statistics. Subsequently, 
we performed an analysis of variance (ANOVA), and a means comparison by the Tukey test $(\mathrm{P} \leq 0.05)$. All percentage data were transformed by $\arcsin \left[(\mathrm{x} / 100)^{1 / 2}\right]$.

\section{RESULTS AND DISCUSSION}

We observed that the level of pest infestation varied among the genotypes tested, from $0 \%$ to $4.22 \%$ of the rhizome, and $0 \%$ to $6.91 \%$ of the plant cortex (Table 1). These differences among the genotypes have been previously reported in the literature at higher levels than observed in this study. For example, in Uganda, KIGGUNDU et al. (2003a) evaluated the infestation of the rhizome borer in different banana genotypes and recorded infestation levels ranging from $0.2 \%$ to $10 \%$.

In the present study, the varieties Prata Anã (AAB) and Pacovan (AAB) were not infested by the banana root borer (coefficient of infestation $=0$ ), suggesting that these materials are resistant to the pest. Although rhizome hardness can affect the insects (ORTIZ et al., 1995), it is likely that the presence of secondary compounds is the main factor that influences the banana root borer. Previous research has shown that resistance to antibiosis strongly affects the banana root borer, since it can influence larval development (ABERA, 2000; NIGHT et al., 2010) and reduced egg viability when the eggs are laid in resistant plants (KIGGUNDU et al., 2007). It has been reported that genotypes susceptible to banana root borer may contain specific volatiles (NDIEGE et al., 1991, 1996), but females have no ability to discriminate between susceptible and resistant genotypes (KIGGUNDU et al., 2007), which may explain the similar distribution of adults reported in the banana orchard in this study.

The chemical components affecting the development of the banana root borer are unknown, but they are likely secondary metabolites, anti-deterrent compounds, or compounds related to the pseudo-latex (GOLD et al., 2001). The lack of borer infestation in the varieties Prata Anã and Pacovan may be associated with these factors; however, and further studies should be conducted to investigate this topic.

Table 1 - Infestation by the banana root borer (Coleoptera: Dryophthoridae) in different banana plant genotypes.

\begin{tabular}{|c|c|c|c|c|}
\hline Treatment (banana plant genotypes) & $\mathrm{CI}^{(1)}$ & Rhizome (\%) infested ${ }^{(2)}$ & Cortex $(\%)$ infested $^{(2)}$ & NPGACC $^{(3)}$ \\
\hline PA 9401 (AAAB) & 10 & $4.22 \pm 0.50 \mathrm{a}$ & $6.63 \pm 1.30 \mathrm{ab}$ & 0 \\
\hline BRS-Tropical (AAAB) & 10 & $4.06 \pm 0.72 \mathrm{ab}$ & $6.91 \pm 1.12 \mathrm{a}$ & 3 \\
\hline BRS-Vitoria (AAAB) & 10 & $3.53 \pm 0.48 \mathrm{abc}$ & $5.58 \pm 1.17 \mathrm{abc}$ & 1 \\
\hline Bucaneiro (AAAA) & 10 & $3.33 \pm 0.19 \mathrm{abc}$ & $5.58 \pm 1.46 \mathrm{abc}$ & 0 \\
\hline YB 4203 (AAAB) & 10 & $2.73 \pm 0.28 \mathrm{abc}$ & $5.26 \pm 1.04 a b c$ & 0 \\
\hline BRS-FHIA Maravilha (AAAB) & 5 & $2.17 \pm 0.51$ abcde & $3.48 \pm 0.97 \mathrm{abcd}$ & 0 \\
\hline BRS-Garantida (AAAB) & 5 & $1.91 \pm 0.62$ abcde & $3.18 \pm 1.03 \mathrm{abcd}$ & 1 \\
\hline FHIA 17 (AAAA) & 5 & $1.69 \pm 0.44$ abcde & $2.75 \pm 0.78 \mathrm{abcd}$ & 0 \\
\hline PA 4244 (AAAB) & 5 & $1.51 \pm 0.50$ bcde & $2.66 \pm 0.68 \mathrm{abcd}$ & 0 \\
\hline BRS-Pacovan Ken (AAAB) & 5 & $1.49 \pm 0.62$ bcde & $2.40 \pm 0.64 \mathrm{abcd}$ & 0 \\
\hline FHIA 02 (AAAB) & 5 & $1.03 \pm 0.34 \mathrm{cde}$ & $2.07 \pm 0.67 \mathrm{abcd}$ & 0 \\
\hline YB 4207-Princesa (AAAB) & 5 & $1.24 \pm 0.35 \mathrm{cde}$ & $2.06 \pm 0.91 \mathrm{abcd}$ & 0 \\
\hline Grande Naine (AAA) & 5 & $1.19 \pm 0.38$ cde & $1.68 \pm 0.80 \mathrm{bcd}$ & 0 \\
\hline PV 9401 (AAAB) & 5 & $1.16 \pm 0.55 \mathrm{cde}$ & $1.03 \pm 0.77 \mathrm{~cd}$ & 0 \\
\hline BRS-Thap maeo (AAB) & 5 & $1.03 \pm 0.92 \mathrm{cde}$ & $1.82 \pm 0.63 \mathrm{abcd}$ & 1 \\
\hline BRS-FHIA 18 (AAAB) & 5 & $0.89 \pm 0.45 \mathrm{cde}$ & $1.43 \pm 0.46 \mathrm{bcd}$ & 0 \\
\hline Caipira (AAA) & 5 & $0.64 \pm 0.09 \mathrm{de}$ & $1.18 \pm 0.50 \mathrm{bcd}$ & 0 \\
\hline BRS-Japira (AAAB) & 5 & $0.55 \pm 0.72 \mathrm{de}$ & $1.80 \pm 0.54 \mathrm{abcd}$ & 1 \\
\hline Prata anã (AAB) & 0 & $0.00 \pm 0.00 \mathrm{e}$ & $0.00 \pm 0.00 \mathrm{~d}$ & 0 \\
\hline Pacovan (AAB) & 0 & $0.00 \pm 0.00 \mathrm{e}$ & $0.00 \pm 0.00 \mathrm{~d}$ & 0 \\
\hline CV $(\%)$ & - & 51.54 & 51.61 & - \\
\hline DF error & - & 100 & 100 & - \\
\hline $\mathrm{F}$ & - & 4.91 & 4.88 & - \\
\hline $\mathrm{P}$ & - & $\leq 0.05$ & $\leq 0.05$ & - \\
\hline
\end{tabular}

(1) Coefficient of infestation (CI), following the methodology developed by MESQUITA (1985) and using the following damage scale: 0 (no galleries present), 5 (traces of galleries observed), 10 (between 5 and 20 galleries present). (2) Means \pm SEM followed by the same letter in the column do not differ by the Tukey test $(\mathrm{P} \leq 0.05)$. All data were transformed using the arcsin formula [( $\mathrm{x} / 100) 1 / 2]$. (3) Number of plants damaged in the central cylinder (NPDCC) could not be analyzed statistically. (-) = parameter non-existent. 
Among the hybrid banana plants, higher pest infestations were reported on PA 9401 (AAAB), BRS Tropical (AAAB), BRS Victoria (AAAB), Bucaneiro (AAAB), and YB 4203 (AAAB) (coefficient of infestation $=10)($ Table 1$)$. Although this study intended to evaluate the infestation in the central cylinder, only $5.83 \%$ of the plants were injured in this region (Table 1), precluding further statistical analysis. It was revealed that $50 \%$ of the hybrid BRS Tropical plants that were assessed were damaged (Table 1). Plant resistance mechanisms still need additional studies, but these preliminary results suggested that these banana hybrids are more susceptible to infestation by the banana root borer. The galleries reported in the rhizome of the plants can compromise its development, affecting not only crop yield but also the longevity of the banana plants (RUKAZAMBUGA et al., 1998). Under conditions characterized by low $\boldsymbol{C}$. sordidus infestation, there are no differences among the genotypes (LINS et al., 2008). Thus, these studies showed that it is important to know the history of banana root borer infestation in an orchard before attempting to develop specific pest management strategies or recommendations as a more adequate genotype to be cultivated in the orchard.

In general, the most suitable hybrid genotypes are PV 9401 (AAAB), BRS Japira (AAAB), and BRS FHIA 18 (AAAB) (Table 1). The cultivation of hybrid genotypes generally has the potential for a higher yield (LIMA et al., 2005; DONATO et al., 2009) and could lead to greater market acceptance. We also reported that the hybrid genotypes PV 9401 (AAAB), BRS Japira (AAAB), and BRS FHIA 18 (AAAB) have a moderate level of resistance to the banana root borer (coefficient of infestation $=5$ ), and the selection of genotypes less prone to infestation will probably benefit production. Conversely, it is important to emphasize that for the successful management of the banana root borer, the establishment of multiple control strategies is needed. This include a focus on increasing plant diversity (DASSOU et al., 2015), biological control through the use of entomopathogenic fungi (AKELLO et al., 2008; LOPES et al., 2013), and the use of pheromones to capture adult pests (REDDY et al., 2009; ALPIZAR et al., 2012).

In Brazil, despite recent technological advances in banana cultivation (LICHTEMBERG \& LICHTEMBERG, 2011), it is necessary to continue developmental studies to better understand the mechanisms involved in the resistance of certain banana plant genotypes to $\boldsymbol{C}$. sordidus, and to compensate for the current lack of data on the topic. This lack of comprehensive knowledge has made it difficult to recommend specific genotypes that will provide the best balance between yield and resistance to $\boldsymbol{C}$. sordidus infestations. Finally, this study provides information that will enable crop managers to come closer to an ideal selection of banana plant genotypes that can reduce susceptibility to infestations of the banana root borer, and meet the technical criteria required by each farming region.

\section{CONCLUSION}

This research demonstrated that the banana genotypes Pacovan (AAB) and Prata Anã (AAB) confer resistance to infestation by the banana root borer. Among banana hybrids, PV 9401 (AAAB), BRS Japira (AAAB), and BRS FHIA 18 (AAAB) showed moderate levels of resistance and lower infestation, while the hybrids BRS Tropical (AAAB), PA 9401 (AAAB), BRS Vitoria (AAAB), YB 4203 (AAAB), and Bucaneiro (AAAA) were the most sensitive to attack by the banana root borer.

\section{ACKNOWLEDGEMENTS}

Authors wish to thank Embrapa Mandioca e Fruticultura, the sponsor agencies Coordenação de Aperfeiçoamento de Pessoal de Nível Superior (CAPES) and Conselho Nacional de Desenvolvimento Científico e Tecnológico (CNPq) for financial support.

\section{REFERENCES}

ABERA, A. et al. Banana weevil Cosmopolites sordidus Germar ovipositional preferences, timing of attack and larval survival survivorship in a mixed cultivar trial in Uganda. Acta Horticulturae, v.540, p.487-496, 2000. Available from: <http://www.actahort.org/ books/540/540_54.htm>. Accessed: Feb. 12, 2015.

AKELLO, J. et al. Endophytic Beauveria bassiana in banana (Musa spp.) reduces banana weevil (Cosmopolites sordidus) fitness and damage. Crop Protection, v.27, n.11, p. 1437-1441, 2008. Available from: $<\mathrm{http}: /$ www.sciencedirect.com/science/article/pii/S0261219408001191>. Accessed: Apr. 14, 2015. doi:10.1016/j.cropro.2008.07.003.

ALPIZAR, D. et al. Management of Cosmopolites sordidus and Metamasius hemipterus in banana by pheromone-based mass trapping. Journal of Chemical Ecology, v.38, n.3, p.245-252, 2012. Available from: <http://www.ncbi.nlm.nih.gov/pubmed/22407283>. Accessed: Apr. 23, 2015. doi: 10.1007/s10886-012-0091-0.

ARLEU, R.J.; SILVEIRA-NETO, S. Broca da bananeira Cosmopolites sordidus (Germar, 1824) (Coleoptera: Curculionidae). Turrialba, v.34, p.359-367, 1984.

DASSOU,A.G. et al. Ant abundance and Cosmopolites sordidus damage in plantain fields as affected by intercropping. Biological Control, v.81, p.51-57, 2015. Available from: <http://www.sciencedirect.com/science/ article/pii/S1049964414002254?np=y>. Acessed: May 14, 2015. doi: 10.1016/j.biocontrol.2014.11.008.

DONATO, S.L.R. et al. Phytotechnical behavior of 'Prata-Anã' banana and progeny hybrids. Pesquisa Agropecuária Brasileira, v.44, n.12, p.1608-1615, 2009. Available from: <http://www.scielo. br/pdf/pab/v44n12/v44n12a07.pdf $>$. Acessed: Jun. 23, 2015. 
FANCELLI, M. et al. Beauveria bassiana strains for biological control of Cosmopolites sordidus (Germ.) (Coleoptera: Curculionidae) in plantain. BioMed Research International, v.2013, p.1-7, 2013. Available from: $<$ http://www.hindawi.com/journals/bmri/2013/184756/>. Acessed: Jun. 14, 2015. doi: 10.1155/2013/184756.

GOLD, C.S. et al. Biology and integrated pest management for the banana weevil, Cosmopolites sordidus (Germar) (Coleoptera: Curculionidae). Integrated Pest Management Reviews, v.6, n.2, p.79-155, 2001. Available from: <http://link.springer.com/article/10. 1023\%2FA\%3A1023330900707\#page-1>. Accessed: Jun. 21, 2015.

KIGGUNDU, A. et al. Levels of host plant resistance to banana weevil, Cosmopolites sordidus (Germar) (Coleoptera: Curculionidae), in Ugandan Musa germplasm. Euphytica, v.133, n.3, p.267-277, 2003 a. Available from: $<$ http://link.springer.com/article/10.1023\%2FA\%3A1 025725124849\#page-1>. Accessed: Apr. 09, 2015.

KIGGUNDU, A. et al. Enhancing banana weevil (Cosmopolites sordidus) resistance by plant genetic modification: a perspective. African Journal of Biotechnology, v.2, n.12, p.563-569, 2003b. Available from: $<$ http://search. proquest.com/openview/dda40e23147c3c39824d4e299c744d70/1.pdf?pqorigsite $=$ gscholar $>$. Accessed: Jun. 23, 2015.

KIGGUNDU, A. et al. Components of resistance to banana weevil (Cosmopolites sordidus) in Musa germplasm in Uganda. Entomologia Experimentalis et Applicata, v.122, n.1, p.27-35, 2007. Available from: $<$ http://onlinelibrary.wiley.com/doi/10.1111/j.1570-7458.2006.00496.x/ abstract>.Accessed: Mar. 22,2015. doi: 10.1111/j.1570-7458.2006.00496.x.

LEMA-LÓPEZ, E.A. et al. Inoculation methods and virulence of Beauveria bassiana (Bals.) Vuill. to Cosmopolites sordidus (Germar) (Coleoptera:Curculionidae) in laboratory. Semina: Ciências Agrárias, v.31, n.1, p.67-74, 2010. Available from: <http://www.uel.br/revistas/uel/ index.php/semagrarias/article/view/4890>. Accessed: Apr. 26, 2015.

LICHTEMBERG, L.A.; LICHTEMBERG, P. dos S.F. Advances on the Brazilian banana crop, Revista Brasileira de Fruticultura, v. esp., p.29-36, 2011. Available from: <http://www.scielo.br/pdf/rbf/ v33nspe1/a05v33nspe1.pdf>. Accessed: Jun. 13, 2015.

LIMA, M.B. et al. Avaliação de cultivares e híbridos de bananeira no recôncavo baiano. Ciência e Agrotecnologia, v.29, n.3, p.515-520, 2005. Available from: $<\mathrm{http}: / / \mathrm{www}$.scielo.br/scielo.php?pid=S1413$70542005000300002 \&$ script $=$ sci arttext $>$. Accessed: May 05, 2015. doi: 10.1590/S1413-70542005000300002.

LINS, R.D. et al. Infestação da broca-do-rizoma em variedades e híbridos de bananeira em Una, Bahia. Magistra, v.20, n.1, p.105108,2008

LOPES, R.B. et al. Diversity of indigenous Beauveria and Metarhizium spp. in a commercial banana field and their virulence toward Cosmopolites sordidus (Coleoptera: Curculionidae). Fungal Ecology, v.6, n.5, p.356-364, 2013. Available from: $<$ http:// www.sciencedirect.com/science/article/pii/S1754504813000767>. Accessed: May 19, 2015. doi: 10.1016/j.funeco.2013.06.007.

MESQUITA, A.L.M. Avaliação do ataque do Cosmopolites sordidus (Germar, 1824) (Coleóptera: Curculionidae) em rizoma de bananeira. Cruz das Almas, BA: Embrapa - CNPMF, 1985. 2p.
NDIEGE, I.O. et al. Volatile components of banana pseudostem of a cultivar susceptible to the banana weevil. Phytochemistry, v.30, n.12, p.3929-3932, 1991.

NDIEGE, I.O. et al. 1,8- Cineole: an attractant for the banana weevil, Cosmopolites sordidus. Phytochemistry, v.42, n.2, p.369-371, 1996. Available from: <http://www.sciencedirect.com/science/article/ pii/0031942296000088>. Accessed: June 6, 2016. doi: 10.1016/00319422(96)00008-8.

NIGHT, G. et al. Survivorship and development of the banana weevil Cosmopolites sordidus (Coleoptera: Curculionidae) on different banana cultivars in Uganda. International Journal of Tropical Insect Science, v.30, n.4, p.186-191, 2010. Available from: <http:// journals.cambridge.org/download.php?file $=\% 2$ FJTI $\% 2$ FJTI30 $04 \%$ 2FS1742758410000329a.pdf \& code $=8$ a1f9da3403d7ca66cb278dbfe 6 e39fd $>$. Accessed: May 22, 2015. doi: 10.1017/S1742758410000329.

ORTIZ, R. et al. Banana weevil resistance and corm hardness in Musa germplasm. Euphytica, v.86, n.2, p.95-102, 1995. Available from: $<$ http://link.springer.com/article/10.1007\%2FBF00022014\#page-1>. Acessed: Mar. 17, 2015.

PAULI, G. et al. West indian sugarcane weevil enhances dissemination of Beauveria bassiana on field populations of the banana weevil. Ciência Rural, v.41,n.11, p.1867-1870,2011. Available from: $<$ http://www.scielo. br/scielo.php?pid=S0103-84782011001100002\&script $=$ sci_arttext $>$. Accessed June 11, 2015. doi: 10.1590/S0103-84782011001100002.

PEREIRA, J.C.R. et al. Occurrence of the Panama disease in banana plants of the subgroup Figo in Piau, Minas Gerais. Fitopatologia Brasileira, v.30, n.5, p.574, 2005. Available from: <http://www.scielo. br/scielo.php?pid=S0100-41582005000500022\&script=sci_arttext $>$. Accessed: Apr. 01, 2015. doi: 10.1590/S0100-41582005000500022.

PRANDO, H.F.; FERREIRA, R.A. Broca-do-rizoma da bananeira. In: SALVADORI, J.R. et al. (Org.). Pragas do solo no Brasil. Passo Fundo-RS: Embrapa Trigo, 2004. p.319-343.

REDDY, G.V.P. et al. Development of an efficient pheromonebased trapping method for the banana root borer Cosmopolites sordidus. Journal of Chemical Ecology, v.35, n.1, p.111-117, 2009. Available from: $<$ http://www.ncbi.nlm.nih.gov/pubmed/19139959>. Accessed: Apr. 01, 2015. doi: 10.1007/s10886-008-9580-6.

RUKAZAMBUGA, N.D.T.M. et al. Yield loss in east African highland banana (Musa spp., AAA-EA group) caused by the banana weevil, Cosmopolites sordidus Germar. Crop Protection, v.17, n.7, p.1-9, 1998. Available from: <http://www.sciencedirect.com/ science/article/pii/S0261219498000568>. Accessed: May 14. 2015.

SADIK, K. et al. A screening method for banana weevil (Cosmopolites sordidus Germar) resistance using reference genotypes. African Journal of Biotechnology, v.9, n.30, p.4725-4730, 2010. Available from: <http:// www.ajol.info/index.php/ajb/article/view/82999>. Acessed: May 12, 2015.

SANTOS, H.G. dos et al. Sistema brasileiro de classificação de solos. 3.ed. Brasília: EMBRAPA, 2013. 353p.

SENGOOBA, T. Survey of banana pest problem complex in Rakai and Masaka Districts in Uganda. Namulonge, Uganda: Namulonge Research Station, 1986. (August 1986: Preliminary trip report). 